\title{
Branding Identity as Da'wah Strategy: Islamic Business Ethics
}

\author{
Chairiawaty $^{1 *}$ \& Kiki Zakiah ${ }^{2}$ \\ ${ }^{12}$ Universitan Islam Bandung, Indonesia \\ *email.chairiawaty@gmail.com
}

\begin{abstract}
This study aims to analyze the branding identity used as a da'wah strategy. Besides, the research is directed to find the concept of Islamic business ethics as a branding identity. This study used the descriptive qualitative method. The object of research is the slogan as one of the branding identities carried out in 10 companies. The results showed that branding identity as a da'wah strategy was carried out in two ways: Qolam (oral and written). Six institutions use Islamic business ethics in their slogans directly and clearly, while four institutions do not state business ethics. The slogan as an Islamic branding identity refers to the principles of communication in Islam, namely Qawlan Sadidan, Qawlan Balighon, Qawlan Karieman, and Qawlan Layyinan.
\end{abstract}

Keywords: Branding; identity; da'wah strategy; Islamic Ethics

\begin{abstract}
$\boldsymbol{A B T R A K}$
Penelitian ini bertujuan untuk menganalisis identitas Branding digunakan sebagai strategi dakwah. Selain itu, penelitian diarahkan untuk menemukan konsep etika bisnis Islam sebagai identitas Branding. Penelitian ini menggunakan metode deskriptif-kualitatif. objek penelitian adalah Slogan sebagai salah satu identitas branding yang dilakukan pada 10 perusahaan. Hasil penelitian menunjukkan bahwa identias branding sebagai strategi dakwah dilakukan dalam dua cara yaitu secara Qolam (lisan maupun tulisan). Sebanyak 6 institusi menggunakan etika bisnis Islam dalam slogan mereka secara langsung dan jelas, sedangkan 4 institusi tidak menyatakan etika bisnis secara langsung dan jelas. Penggunaan slogan sebagai identitas branding Islam merujuk pada prinsip komunikasi dalam Islam yakni Qawlan Sadidan, Qawlan Balighon, Qawlan Karieman dan Qawlan Layyinan.
\end{abstract}

Kata Kunci: Branding; identitas; strategi dakwah; etika Islam. 


\section{INTRODUCTION}

A strategy is an effort to achieve goals, including disseminating information or religious teachings (da'wah) (Katu (2012: 28). A variety of strategies is used which certainly requires technique as a more specific and more operational way (Mahmuddin, 2013: 38). The purpose of a strategy is to win or achieve the desired results (Mahmuddin, 2013: 37).

Da'wah is the actualization of faith which is manifested in a system of activities of believers in the social field. Nawawi (2016) stated that Dakwah is not only normative understanding of Islamic values, but also understanding human and environment condition as dakwah's target which is obliged for every Muslim as our Prophet Muhammad said in one hadith that "Allah does not punish a whole community on the sins of a small group of people, until these people transgress openly, before such people who have the power of preventing them and yet do not do so". The activity of da'wah takes a strategy. Da'wah strategy is an effort or activity carried out in order to achieve the objectives of da'wah (Arifin \& Suharto, 2016) Da'wah is a part of communication (Saufi Afliga, 2018) where in the era of the rapid development of internet technology, makes people use new media to access all their needs. With the existence of new media, it emerges da'wah communication through new media. Da'wah Communication uses new media as a new forum for Ulama, Community Organization, and educational institution in spreading syiar of Islam. A proper Dakwah strategy (Ariyanto, et.all, 2019) will give best solutions for any problems faced by umat.

Da'wah in marketing area is a communication activity carried out by buyers and sellers. In addition, marketing communication is also an activity that helps making decisions in the field of marketing and direct exchanges to be more satisfying by making all parties aware of doing better. Marketing communication (Shimp, 2003) is an important aspect in the overall marketing mission and determinants of marketing success. Marketing communication can be understood by outlining two main elements, namely communication and marketing. Communication is a process of thought and understanding conveyed by individuals or between organizations and individuals. Marketing is a collection of activities in which companies and other organizations transfer values (exchanges) between them and their customers.

Marketing activities which have all activities designed to generate and 
facilitate any exchanges intended to satisfy human needs or wants, such that the satisfaction of these needs and wants occurs, with minimal detrimental impact on the natural environment (Jung, Kim, \& Kim, 2020)" are a 'halal' way that a Muslim can do to make a profit. Marketing activities (especially: selling / commerce) involve muamalah worship in Islam. In matters of muamalah, Islam does not narrowly limit humans, but rather makes it easy for his servants. Islamic teachings provide opportunities for humans to innovate, especially in the field of muamalah including marketing activities to make it easier in everyday life. Islam has never banned its people from doing business. Prophet Muhammad has shown that Islam is very concerned upon "business" (commerce) as a livelihood for its people. But in business, Islam has determined its guidelines.

Branding is part of communication activities. Brand on one hand is labeling that has the power to boost sales of a product. Brand can also be linked to consumer trust for a product or service that is trusted not only to meet their needs, but to provide better satisfaction and a guarantee. Brand is considered as one effective sales strategy. Apart from being an identity, brand will make consumers trust and loyal to the product. There is emotional bonds that impress consumers with the product concerned. This bond is what keeps the consumer from going consider other brands, even if they cost cheaper. We can see how many consumers there are fanatical about a particular brand, and not switch to another brand even though there are other brands for similar products that may be relatively the same quality and the price is just a lot cheaper.

On the other hand, Brand is also a company promise to customers. Through a brand the company will tell its customers what they can expect from products and services these companies, and this is what will differentiate the service of a company than those offered by other competitors. Brand is formed from who you are (company) actually, who do you want, and who that person you want to receive. When the information is packaged in such a way in a slogan of a company "Brand", to be conveyed to consumers, then the company's reputation will be at stake. That is why Brand especially company slogan is a company commitment to the products or services launched.

Da'wah in branding can be part of Islamic teaching, in which Islam has put up some rules and guidances how to brand or promote the products properly, accurately, legally, fairly, honestly, and well accepted. In business world, as we can see, we still find some branding identities that do not use 
the business ethics let alone the Islamic business ethics. Islam provides rules as branding identity ethics that must be followed, namely: sincerity, commitment, exemplary, honesty, brotherhood, education, and humility. Likewise, the words used in branding must be in accordance with Islamic principles, namely Qawlan Ma'rufan, Qawlan Sadidan, Qawlan Baligho, Qawlan Karieman, and Qawlan Layyinan

This paper will discuss how the Da'wah Strategies in "Branding Identity" in terms of Islamic Business Ethics. Some previous research about da'wah strategy and branding identity have already been conducted by some researchers, among othera are: Nawai (2008) conducted the research entitled "The Dakwah Stretegy, A Study of Problem Solution" He found out that Da'wah Bil Hal is expected to support aspects of community life so that ultimately each community has the ability to address the needs and interests of its members, particularly in the fields of economy, education and public health.

Jumani and Siddiqui (2012) conducted a study of 100 students in Pakistan on Islamic Branding. Their research results state that perception as a moderating variable has more influence on Islamic Branding than their level of monotheism. This means that students choose a product (Islamic brand) based on their perception of the product compared to the level of monotheism.

Yunus (2012) conducted research on Muslim consumers in nonMuslim countries (Australia) and consumers in Muslim countries (Malaysia). The results of this study indicate that both Muslims in Australia and in Malaysia sometimes do not just believe in products that are certified halal, they will further investigate the ingredients.

From those three research mentioned., the difference of this research with those three research is that none of those research mentioned used the Islamic Business Ethics in their study, yet this research discussed the da'wah strategy in branding identity viewed from Islamic high moral business guidances, as already mentioned above.

The research method used is descriptive qualitative so that the research objectives can be achieved comprehensively, by photographing the object of research, namely Corporate Branding Identity which is focused on the slogans the company uses. The research subjects were 10 companies, both private and government. The purpose of this research is to find out how sincerity, commitment, exemplary, honesty, brotherhood, education, and humility are used as Da'wah strategies in Branding Identity; 
and how Qawlan Ma'rufan, Qawlan Sadidan, Qawlan Baligho, Qawlan Karieman, and Qawlan Layyinan as Islamic business ethics are used in Branding Identity. This paper is expected to contribute to da'wah strategies in marketing communications, especially using Islamic business ethics for Branding Identity.

\section{RESULT AND DISCUSSION}

\section{Branding Identity: Between Ethics and Islamic Business Ethics}

The term brand has a number of contributions that make branding an important element for firmsas a factor affecting the firm's activities in the market. The contributions shown are as follows : (a) the items ofbrand equity support high-level pricing where a company findsdevelopment opportunities through brand expansions, (b) the firmprovides an advantage to enter or maintain the distributionchannel and, ultimately, offers the company the opportunity tohave a competitive advantage enabling to interfere with competitors (Bank, Yazar, \& Sivri, 2020). Branding can be likened to labeling which has the power to help sales.

The term brand appears when product competition is increasingly sharp which causes the need to strengthen the role of labels to classify products and services so that it is different from other product and service groups. One of the efforts made by companies to penetrate markets and strengthen products or services is by branding.

Branding is an effort to strengthen the position of the product in the minds of consumers by adding equity to the name of a group of products (Soemanagara, 2006: 98-99). Say, the brand of an electronic device, such as television, which is very well known by the public. To strengthen the position of the brand in the minds of consumers, the company requires product equty efforts, namely reaching other citizens, for example Mobile phones, with the same brand.

Many brands of various products or services in circulation all offer similar promises, but successful brands or brands are brands that have an important history of mastering information, especially about the advantages of non-brand products with positive experiences felt by customers on these products. Branding can be a guarantee that other products offered have almost the same strength, which is close to the level of "perfection", even though the word perfect has never been reached and can never be proven. The branding business processes related to how many consumers receive the product's strength information are clearly successful 
because they share many product campaign efforts. Quality products are produced by high human resource capacity.

Branding is part of marketing communication activities. Marketing communication activitiesshape attitude while attitude determine customer loyalty (Zephaniah, Ogba, \& Izogo, 2020) cannot be separated from the study of marketing strategies, one of which is promotion. Effective and efficient promotional activities are part of the marketing communication mix concept which according to Kotler (2004) consists of 4 Ps, namely: product, price, place, and promotion.

The communication mix is also always associated with the activity of delivering messages about: goods, services, experiences, activities, people, places, ownership, organization, information, and ideas. Therefore, Branding is also a form of delivering messages about a product or service. Through branding, a company can risk its reputation.

Brands (Golossenko, Pillai, \& Aroean, 2020) that can be names, logos, slogans, and other symbols can distinguish a product or service from competitors with the criteria contained in it more broadly referring to what is called identity. Brand identity (Kristal, Baumgarth, \& Henseler, 2020) or brand is a set of unique brand associations created by brand strategists. These associations reflect the position of a brand and are a promise to customers. Brand identity will help the stability of the relationship between brands and customers through a value proposition that involves functional benefits, emotional benefits or self-expression.

Brand identity is the value of a brand that does not change over time. Brand identity is the individuality or personality of the brand, which is the result of the formulation of the brand concept by the owner or management which will then be used as a basis or reference in formulating brand meaning to form perceptions and subsequently establish relationships with consumers. Brand identity explains the "who" the brand is related to. With a strong identity and in accordance with the productcategories supported by the right strategy, the brand will succeed in increasing its brand equity.

The key for building a strong lines in how management formulates a brand identity is in line with the company's vision and can be realized in the culture and existing value systems. The key to maintain the identity formed is always to maintain the consistency of quality in every point of contact of the brand with consumers. The distinction between products and brands according to Aaker (Soemanagara, 2006) can be used as a guide 
to clarify identity. Products include scope, attributes, quality, and usage. While brands include symbols, brand personalities, all associations to the organization, country of origin, user imagery, the benefits of selfexpression, emotional benefits, and the relationship between brands and customers.

According to Aaker brand name is a core indicator for a brand that is the foundation for communication efforts and awareness creation. So that brand names are actually the essence of the brand concept. Effective brand names can be utilized to create the first message for special positioning. Brand names must be able to work easily with other information, support symbols, align with slogans, show desired associations, do not lead to unwanted associations, and have distinguishing features so consumers are not confused with competing brand names (Kotler, 2004).

Other information that supports Brand Name is the slogan. The slogan that is part of the brand having a role that is no less important than the brand name. The slogan is very important in Branding as a campaign management activity. For example, the slogan owned by Metro TV "Knowledge to Elevate", is a company campaign that identifies "Metro TV is obliged to give high education, science and understanding to its costumer". The slogan is a promise or commitment which are the mandates. If this is nott fulfilled, it will result disappointment and dissatisfying to all the costumers. If the commitment is violated, the company's image will not be good in the eyes of customers, which will cause the company's reputation to decrease, because the level of consumer confidence also decreases, and as a result the company will lose customers. Therefore, when a company will provide a label in the form of a slogan on the company's products or services, then by that time the company has come into a contract in the form of an appointment with the customer. This is the commitment made, and at that moment the ethics and morals of all company management are at stake, so it is very important to look at the ethics and morals in business deeper.

In Britanica Encylopedia ethics is stated as moral philosophy, namely a systematic study of the nature of the concepts of good, bad, must, true, false, and so on, it still cannot provide a complete picture of how ethics can be used in various aspects of human life. Ethics encompasses all acceptable personal and social behavior, from the rules of "everyday manners" to the stance that determines the type of work we do; who are friends; and the 
ways we relate to family and others. On the contrary, morality is more specific, and is part of ethical law. Its use is special. People who do not keep verbal promises, we consider people to be untrustworthy or "unethical". So, it's not "immoral". But, torturing children or poisoning a daughter-inlaw or father-in-law, we call it an immoral act (so, there is an emphasis on the seriousness of the offense). Morality consists of the basic laws of a society which is the most essential and very powerful (Solomon, 1987).

Ethics, as said by Magnis-Suseno (1991: 14), is not an additional source of moral teaching but rather philosophy or critical and fundamental thinking about moral teachings and views. In other words, ethics is a science, not a teaching. So, ethics and moral teachings are not on the same level. Morallah teachings that we must live, not ethics. Ethics wants to understand why we must follow certain moral teachings, or how we can take responsible attitude towards various moral teachings.

When dealing with moral teachings, it contains the values of goodbad, right-wrong, accepted or not a behavior according to certain norms, rules, teachings, and laws. In the teachings of Islam, good and bad judgments are known as ahlak. The word "morals" comes from Arabic, khalaqa. The word origin is khuluqun (plural), which means temperament, character, character, or behavior (Saefuddin, et al., 1987: 200). This word contains aspects of correspondence with the words khalqun which means "event," and is closely related to khaliq which means "creator," and makhluq which means "created". Thus, the formulation of the notion of "morals" arises as a medium that allows for good relations between the Creator and beings, as well as between beings and beings.

The word morals are also often interpreted as ethics. Thus, what is meant by morals is the positive and active power obtained by a person to shift his inner situation (his natural tendency) to moral quality (Ali, 1987: 371). So, if there are some people who think that ethics is the same as moral, equality does exist; both discuss the problem of the merits of human behavior. In the Islamic view, morals are science that teaches what is good and what is bad based on the teachings of Allah SWT and His Messenger.

Based on the understanding of the language above, it can be said that morals, or behavior systems, are realized through the application system of values and or norms that originate in the Koran and Sunnah. Unlike the ethics that are formed from the system of values and or norms that apply naturally in society and can change according to the agreement and agreement of the community at certain dimensions of time and space, the 
ethical system is completely free of values and free from hablumminallah (relationship with God).

Ethics according to Al-awani (2005: 4) is a model of behavior that should be followed to harmonize human relations, minimize distortion, and function for the welfare of society. Ethics contained in business literature is based on opinions about business ethics. Specifically these are classified into the following business fields: (1) business ethics practices; (2) individuals and organizations; (3) corporate social responsibility and principles; (4) corporate social responsibility and practices, (5) market economy ethics principles; (6) ethics in accounting and auditing practices; (7) ethics in marketing practice; (8) ethics in personal management practices, and (9) ethics in investment practices.

Whereas morality in Islam is very extensive in a wide and comprehensive manner. Islamic morality is related to all aspects of human life, related to the relationship between humans and God, humans with each other, and other creatures in the universe. The area of morality in Islam includes faith in God, religious rituals, spiritual obedience, social behavior, decision making, dating science, habits of consumption, awareness in speech, and all other aspects of life, including business. The moral and business ethics principles in Islam are covered in the Qur'an and Hadith, which consist of: (1) Truth, (2) Trust, (3) Sincerity, (4) Brotherhood, (5) Science, and (6) Justice (Hanafi \& Al Awani, 2005: 3639).

The principle of truth has profound implications for business behavior. A business person should be honest, determined, correct, and straight in all business agreements. There is no room for fraud, lying, and deceptive advertising in the frame of Islamic business. Amanah is a fundamental ethical ethical principle of Islam, the essence of which is a sense of responsibility, with the principle of trust that business people will not do anything to add to or destroy society or the environment. Furthermore, Islam also emphasizes the importance of sincerity in intention and behavior in every step of life. Sincerity results in more efficient work and higher productivity, and reduces manipulation or exploitation of others for personal reasons. Business activities must also be able to shape the attitude of business people who do not look at race, color, ethnicity, caste, or language, and must be able to grow knowledge for related parties. The last principle of Islamic business ethics is fairness which means that all people / consumers are treated properly, without improper 
obligations.

\section{Da'wa Srategies in Islamic Branding Identity}

Da'wah teaches people that Islam comes with grace for all nature and of course even more so for its adherents. However, it is unfortunate that this blessing has not been felt to touch the real life aspects of Muslims, especially those who live in rural areas. This is because what has touched them from religious teachings so far is only the aspects of ritual worship, while other aspects, even if touched and carried out only in an individual, and in a collective form, are still very few and less effective.

Da'wah strategies used in marketing communication especially in promoting and branding the products or services uded by institutions and corporates studied consist old two ways, those are: By Qolam (Orally) that are used in both oral and written information, and Da'wah by Hal (Practice) thar are used by the persons involved in the promotion activity. The Da'wah of Bil Hal is expected to support aspects of community life so that ultimately each community has the ability to address the needs and interests of its members, especially in the fields of economy, education and public health.

Basically, Branding or advertisements have the primary purpose of marketing the products, with the target of increasing imaging which ultimately increases sales. The case of quality of goods / products can be accounted whether the orders are in the list or not. If this is the case, then what is actually happening is duping efforts for the consumer. In fact, what actually happened next was market law, mutual claims, mutual badmouthing competitors and propaganda of their own superiority compared to others. In fact, there are not a few labels as advertisements that do not heed ethics.

Such conditions can actually be avoided, if only if the "producers" or corporations apply "ethics" in advertising themselves, which is actually inherent in branding (especially in the slogan) is the luxury of the institution or organization. Not only that, through the words packaged and campaigned "they" actually also represent the entire contents of the institution. That is why when packaging messages through words in slogans, for example, a corporate or institution must also think of all the things that represent it.

Islamic Ethics provides signs in conveying messages in branding or advertising as follows: firstly, sincere (sincerity). Delivering messages 
through campaigns or links in Islam is part of pious deeds and worship, therefore it must be noted the sincerity of intention and sincerity of motivation, as stated in the Qur'an Surah Al Baqarah verse 5, "Even though they were not told to worship Allah with purifying obedience to Him in practicing religion straightly. Secondly, tha'ah (obedience/commitment). The branding used must always follow the applicable rules or company directives regarding the campaign as a form of obedience to Ulil Amri. "And among people there are people who use words that are not useful to lead people astray from the way of Allah without knowledge and make the way of Allah ridicule. They obtain humiliating punishment (QR. Luqman: 6). Thirdly, uswah (exemplary). Displaying and conveying company activities must be in the best way and example. Among the best and sympathetic branding ethics is to promote the superiority of products or services without vilifying and ridiculing the products or services of other companies. The Messenger of Allah said, "Verily, Allah is obliged to do his best in all matters. Apart from that advertising is an effective advertisement by means of using language and behavior that entice and attract the sympathy of people.

Fourthly, siddiq (honesty). Honesty is one of the keys to marketing success. Therefore, selling out a promise without realizing it is an act that is full of lies, and lying is one of the great sins. Said the Prophet, "Hold on to honesty, because honesty shows you the good, and goodness is a path to heaven." The slogan giving by IWU "committed to excellent service", must show the real implementation in their academic practice and atmosphere. Fifthly, ukhuwah (brotherhood). Branding is not an arena to satisfy appetite and lust. The words that are spoken, the symbols that are displayed must always reflect brotherhood, must not be prejudiced, let alone make accusations that are unreasonable, which will lead to tensions and feuds that foster fraternity. God's Word in QS. Al Hujarat 10-12, "Surely the believers are brothers, therefore reconcile between your two brothers and fear Allah so that you may have mercy." While the words of Rsulullah, "Abusing a Muslim is an ungodliness, and killing him is an infidelity."

Sixthly, tarbawy (educative). Branding is also an educational tool that must uphold moral values and politeness, besides being a means of da'wah that has the meaning of inviting in a persuasive way, not coercive or intimidating. Therefore branding must have a commitment to educational values. God's Word in QS. Al Baqarah 256 clearly states, "There is no 
compulsion to enter the religion of Islam, in fact it is clear the right path rather than the wrong path." Seventhly, tawadlu (humility). Islamic morality requires that a group does not consider the group to be the most correct, nor is it easy to accuse others of making a deviation. Conveying superiority of self or class is okay, but does not relate it to the shortcomings of other people / groups. QS An-Najm 32, which means: "Then do not say that you are pure. He is the one who knows the most pious ".

Table 1. The slogan Islamic Branding used by 10 Corporates

\begin{tabular}{lll}
\hline No & \multicolumn{1}{c}{ Korporasi/Institusi } & Slogan \\
\hline 1 & Metro TV & Knowledge To Elevate \\
2 & SCTV & Actual, Tajam, Terpercaya \\
3 & RCTI & Kebanggaan Bersama Milik Bangsa \\
4 & B- Channel & Inspirasi Keluarga Anda \\
5 & Trans 7 & Aktif, Cerdas, Menghibur \\
6 & Telkom Indonesia & Committeed To You \\
7 & KPK & Berani Jujur Itu Hebat \\
8 & Kemendikbud & Merdeka Belajar \\
9 & Kemenhukam & Kami Pasti \\
10 & Provinsi Jawa Barat & Jabar Juara Lahir Bathin \\
\hline
\end{tabular}

Source: observation, 2020

From the slogans used by 10 corporates, 6 corporates stated directly the corporate's values, for example: knowledge to elevate which means that the corporate concerns a lot to make public have wide insight and good knowledge. This is in line with what Islam guides for Branding, that is Tarbawy or Educative. SCTV slogan: actual, sharp and trustable. This slogan is in accordance with Islamic ethics "Uswah" or Exemplary and siddiq. The slogan used by PT Telkom Indonesia and KPK is in line so much with Islamic ethics "Siddiq" or Honest. The slogan of West Java Province "Jabar Juara Lahir Bathin" puts up all the Islamic ethics in its branding, those are Sincere (sincerity), Tha'ah (Obedience)/Commitment), Uswah (Exemplary), Siddiq (Honest), Ukhuwah (Brotherhood), Tarbawy (Educative), and Tawadlu (Humility).

The slogan of Kemenhukam PASTI (Professional, Accountable, Sinergi, Transparant, Innovative) shows all Islamic ethics describing sincerity to work hard, upholding professional ethics and integrity; being accountable to the public in accordance with the applicable provisions or regulations; having high commitment to build productive cooperative relationships and harmonious partnerships with stakeholders to find and 
implement the best, useful and quality solutions; opening access or freedom for everyone to obtain information about governance,; supporting creativity and developing initiatives to always make reforms in carrying out its duties and functions.

In addition to the conditions above, Da'wah in marketing provides signs in Branding Identity, which has characters containing Islamic rules in the way of delivery, in Islamic ethics for branding in this case advertising must also underlie the use of words or symbols. symbols used in accordance with Islamic rules, such as recommending that the slogan use words that are appropriate, proportionately, that are easily digested by others, and do not cause various interpretations. In the Qur'an, Surat 26, verse 26, Allah commands that believers use good words (proper and human sentences). Even Allah SWT further believes "Say to them appropriate speech, which does not offend their honor (Q.S Al-Isra '28).

Islam never requires the use of winged words, such as "there is no collusion, only deviations of procedure. Winged sentences like this, if continued to be cultivated and said by leaders, will lead to a decline in the authority of leaders in the eyes of the public. And in turn the community will make the assumption: "If the leader says something, of course what is meant is the opposite", so it's as if our community is always "educated" to draw conclusions in reverse.

The Qur'an provides various examples of words which can be said to be compound words that have various connotations of meaning. The good, friendly figurative words in the Qur'an are expressed with "Qawlanma'rufan" (S. Al-Baqarah 235) and the correct and decisive words, "Qawlansadidan" (S. An-Nisa 9) in terms of words it's honest, not outsmarting, and not hypocritical,

The definite words called Qawlan Baligo, is the third corridor that is required by Allah SWT, to humans when they will be blessed, that is, words that are expected to give a deep trace into the heart of the person who receives it. Allah Almighty says in the An-Nisa'63 letter which means "they are (hypocrites are those who Allah knows what is in their hearts. Therefore, you turn away from them, and give them a lesson, and say to them the words that have marks to their souls. "In addition, the gentle and respectful words of" Qawlan karieman "are recommended in the Qur'an, Surat Al-Isra '23. This is a manifestation of sincere and sincere love.

Furthermore, we are instructed to use the word soft, polite and wise words especially addressed to the tyrannical ruler. This word "Qawlan 
layyinan" (QS. Thaaha, 41) for example, was instructed by Allah to Moses and Aaron, as a word which has the dimension of preaching to Pharaoh. who are considered to be memorable in his heart, and are likely to welcome his invitation. Thus, Islam has given clear limits to anyone when he will provide information to others, especially if he will give a promise. There are four ethics or signs given by God towards this matter, that is: Qawlan Sadidan; Qawlan Baligho; Qawlan Layyinan; dan Qawlan Karieman.

\section{CONCLUSION}

Branding identity that can be shown in slogan of a certain institution can be used as Da'wah media. As has already been understood that Da'wah can be conducted in every field of human life including in marketing. Da'wah is religious communication, and in marketing communication Da'wah can be taken by using Slogan. Based on the result of the research the strategies of Da'wah taken in branding the products or services used by institutions studied consisted of two ways, those are: By Qolam (Orally) that used both oral and written communication, and Da'wah By Hal (Practice) that are used by the persons involved in the branding activity.

Branding as a marketing strategy used by the institutions/corporates observed is generally aimed at form the image of a product or service that can impress the public. Slogan as one of branding identities is indeed considered to be the most effective and efficient tool in promoting products or services to the public. Slogan is also Da'wah media that can show the corporate ethics used. Islamic ethics used in a slogan consist of : truth, honesty, decisiveness, sincerity, certainty, and consistency. The result of the resarch show that 6 coporates out of 10 show directly the Islamic ethics used in their slogan, whereas 4 corporates did not show direclty the Islamic ethics upheld. Two (2) institutions can show that they uphold all the Islamic ethics in their branding. For the words used in the slogan most of the institutiona can show Qawlan Sadidan, Qawlan Baligho; Qawlan Karieman, and Qawlan Layyinan in their message/information.

\section{REFERENCES}

Arifin, A., dan Suharto, A. (2016). Jurnal PKS Vol 15 No 1 Maret 2016; 25 - 34201: 227 Adi Suharto.2016. pkes vol. 15. No.1 Maret:25 -34.

Ali, H. A. (1987). Beberapa Persoalan Agama Dewasa ini. Jakarta: Rajawali Press. 
Ariyanto, B., Firosyurahman, M., Mangkarto, M.R.K., \& Fatoni, U. (2019). Strategi Komunikasi Dakwah dalam Pembinaan Mental Narapidana, Jurnal Sahafa Journal of Islamic Communication, 1(2).

Bank, S., Yazar, E. E., \& Sivri, U. (2020). The portfolios with strong brand value: More returns? Lower risk?, Borsa Istanbul Review, 20(1), 64-79. https://doi.org/10.1016/j.bir.2019.09.001

Golossenko, A., Pillai, K. G., \& Aroean, L. (2020). Seeing brands as humans: Development and validation of a brand anthropomorphism scale, International Journal of Research in Marketing, (xxxx). https://doi.org/10.1016/j.ijresmar.2020.02.007

Jumani and Siddiqui. 2012. Bases of Islamic Branding In Pakistan: Perception or Believes, On Interdisclipinary Journal of Contemporary research in Business, 3(9).

Jung, J., Kim, S.J., \& Kim, K. H. (2020). Sustainable marketing activities of traditional fashion market and brand loyalty, Journal of Business Research, (August 2019), 1-8. https://doi.org/10.1016/j.jbusres.2020.04.019

Katu, S. (2012). Taktik dan Strategi Dakwah di Era Millenium (Studi Kritis Gerakan Dakwah Jammah Tablig), Cet. II; Makassar: Alauddin University Press.

Kristal, S., Baumgarth, C., \& Henseler, J. 2020. Performative corporate brand identity in industrial markets: The case of German prosthetics manufacturer Ottobock, Journal of Business Research, 114 (May 2019), 240-253. https://doi.org/10.1016/ j.jbusres. 2020.04 .026

Kotler, P., \& Amstrong, G. (2004). "Principle of Marketing", $10^{\text {th }}$ edition. International Edition, Prentice Hall, New Jersey.

Magnis-Suseno, F. (1991). Etika Sosial. Jakarta: Gramedia

Saufi Afliga, M. N. A. (2018). No Title. Jurnal of Islamic Communication, Vol.1.

Nawawi, N. (2016). Strategi Dakwah Studi Pemecahan Masalah, KOMUNIKA: Jurnal Dakwah Dan Komunikasi, 2(2), 269-276. https://doi.org /10.24090/ komunika.v2i2.107

Saefuddin, J. A. (2008). Pemikiran Kontemporer Administrasi Publik, Perspektif Manajemen Sumber daya Manusiadalam Era Desentralisasi. Bandung: LP3AN

Solomon, R. C. (1987). Etika, Suatu Pengantar (penerjemah R. Andre Karokaro). Jakarta: Erlangga

Soemanagara, R. D. (2006). Strategic Marketing Communication, Konsep Strategis dan Terapan. Alafabeta: Bandung. 
Shimp, T. A. (2003). Periklanan Promosi Aspek Tambahan Komunikasi Pemasaran Terpadu Jilid I. Jakarta: Erlangga. 4.

Yunus, A. (2012). Halal Branding: A Study of Moslem Consumers Perspective, Proceedings of The 2nd Global Islamic Marketing Conference. Abu Dhabi, Pp 1-6

Zephaniah, C. O., Ogba, I. E., \& Izogo, E. E. (2020). Examining the effect of customers' perception of bank marketing communication on customer loyalty, Scientific African, 8(4), 1-11. https://doi.org/10.1016/ j.sciaf. 2020.e00383 